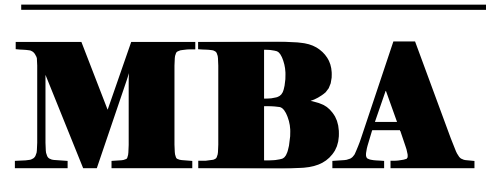

Vol. 4 , No. 2 , July 2021, page 455 - 462

ISSN 2614-1981 (Print)

ISSN 2615-0352 (Online)

Journal of Management and Business Aplication

\title{
THE IMPACT OF COVID 19 IN THE DEVELOPMENT OF THE STUDENT BUSINESS GROUP OF THE ACCOUNTING STUDY PROGRAM AT THE AKADEMI AKUNTANSI PGRI JEMBER
}

\author{
SUWARSO \\ Akademi Akuntansi PGRI Jember \\ 5uw2r50@gmail.com
}

\begin{abstract}
This study aims to determine the impact of covid 19 in the development of the student business group of the accounting study program at the Akademi Akuntansi PGRI Jember 2021. The method used in this research is direct observation in the field. From the results of research on several student businesses, various findings were obtained. This research is qualitative in nature with samples taken from students who carry out business activities. The results of this study indicate that the impact of covid 19 in the development of business groups of students in the accounting study program at the Akademi Akuntansi PGRI Jember of Accounts has two impacts, namely positive and negative, that this student business group experiences problems with decreasing product processing, promotion / advertising increases but decreases in sales, prices and services. experienced an increase with a low profit level, the relationship between business members was maintained well, while the customers continued to establish a more communicative relationship, there was an increase in high enthusiasm for striving earnestly and willing to learn
\end{abstract}

Keywords: Business, Students, Covid 19.

\section{INTRODUCTION}

The world economy at the beginning of 2020 was shaken due to the rapid spread of Covid 19 (corona virus), because many countries implemented Lock Down in their respective countries to prevent the spread of this virus. With the many implementations of Lock Down in various countries, the world's economic sector has experienced paralysis. Indonesia did not escape the spread of the corona virus at the end of February or early March 2020. Of course, as with countries affected by the corona virus, Indonesia also implemented Large-Scale Social Restrictions, so that the Indonesian economy also experienced an economic decline.

The corona virus or corona virus disease 2019 (Covid-19) has made the domestic economy contract. The Ministry of Finance (Kemenkeu) at least noted that there were eight harms caused by the virus outbreak. First, as of April 11, more than 1.5 million employees had dropped out of work 
or were laid off and furloughed. Of which 1.2 million workers come from the formal sector, 265,000 from the informal sector. Second, Indonesia's Purchasing Managers Index (PMI) is below level 50, which is only 45.3 in March 2020. Third, more than 12,703 flights at 15 airports were canceled during January-February, with details of 11,680 domestic flights and 1,023 international flights. Fourth, around IDR 207 billion lost revenue in the air service sector, with around IDR 48 billion lost contributed by flights from China. Fifth, the number of tourists decreased to 6,800 per day, especially tourists from China. Sixth, the Indonesian Hotel and Restaurant Association estimates that the decline in occupancy rates at around 6,000 hotels in Indonesia can reach 50 percent. This could affect the decline in tourism foreign exchange more than half last year. Seventh, Indonesia's imports during January-March 2020 fell $3.7 \%$ year to date (ytd). Eighth, inflation in March 2020 was recorded at $2.96 \%$ year on year (yoy) contributed by the increase in the price of gold jewelry and several soaring food prices. However, there was deflation in various chili commodities and air freight rates.

Entrepreneurial students of the accounting study program of the PGRI Jember Accounting Academy, of course, also feel the big impact of this corona virus on products, both goods and services that will be marketed. Because most of these entrepreneurial students mostly market their products in the campus area, while the campus itself started at the end of February, there have been many online lectures (on the network), so that many of these entrepreneurial students face many obstacles. Seeing this phenomenon made the author interested in analyzing the impact of this corona virus in the business development of entrepreneurial students.

\section{Formulation of the problem}

From the description of the background above, the main problem can be formulated as follows: How is the impact of covid 19 in business development for students of the accounting study program at the Akademi Akuntansi PGRI Jember.

\section{Research Purposes}

Based on the formulation of the problem, the purpose of this study is to find out the impact of covid 19 in business development for students of the accounting study program at the Akademi Akuntansi PGRI Jember.

\section{LITERATURE REVIEW}

\section{Impact}

Impact; 1. Colission 2. strong influences that have consequences (both negative and positive) 3. a collision large enough between two objects to cause a significant change in the momentum (centres) of the system experiencing the collision.

Economical, the influence of an activity on the economy;

Negative, strong influence that has negative consequences;

Positive, strong influence that has a positive effect.

\section{COVID-19}

COVID-19 is an infectious disease caused by a newly discovered type of coronavirus. This new virus and the disease it causes were unknown before the outbreak began in Wuhan, China, in December 2019. COVID-19 is now a pandemic occurring in many countries around the world.

\section{Business}

According to Kasali et al (2010:13) real business is a vast ocean that an entrepreneur is engaged in. He doesn't know shortcuts, let alone how to get rich quick. 


\section{Businessman}

According to Madya et al in his book (2006:4) the definition of entrepreneurship from entrepreneurship experts is someone who is able to face risk and uncertainty because they produce at a certain cost and resell the goods at a certain price.

\section{Business development}

Business development is the task and process of analytical preparation of potential growth opportunities, support and monitoring of the implementation of business growth opportunities, but does not include decisions on strategy and implementation of business growth opportunities. Hendro (2011)

According to French et al (2000) definition of business development is a powerful set of concepts and techniques to improve organizational effectiveness and individual well-being.

From some of the expert opinions above, it can be concluded that business development is a concept that must be prepared in starting a business by looking at existing opportunities to increase the effectiveness of business growth.

\section{Business Development Strategy}

A business that is well known by many people and generates profits is called a developed business, such a business is what all business actors want to achieve. We realize that when we have succeeded in building/starting a new business, the next challenge is how to develop the strategy and how to develop our business so that it produces something as we expect. The core and outline of business development is marketing and maximizing profit, there are several things that can be done in marketing and profit maximization, the following are strategies and ways that we can do in an effort to develop a business:
1. Strategi dan cara yang pertama ini adalah dengan melakukan pengolahan terhadap produk yang dimiliki, kita bisa melakukan inovasi terhadap produk agar berbeda dan terlihat lebih menarik dari produk yang lainnya, ataupun kita bisa melakukan perbaikan terhadap produk agar dapat bersaing dengan produk-produk lain. Inti dari strategi dan cara mengembangkan usaha yang pertama ini adalah produk yang kita miliki tidak boleh kalah dan harus bisa bersaing dengan produk lainnya.

2. This second strategy and method is to develop by doing promotions/advertising consistently, if we introduce our products continuously or consistently as a result, consumers will not easily forget the product brands that we offer, and it is hoped that our products can be considered by consumers.

3. The third strategy and way to develop a business is to provide affordable and competitive prices, and provide maximum service to consumers/customers. Do not give a price that is too high, do not be too greedy. We just need to make sure that we don't suffer losses, and provide the best possible service to consumers and customers so that they can directly assess our superior performance

4. The fourth strategy and method is to try to establish a harmonious relationship with the internal and external parties of the company. External parties can include distributors, suppliers, or customers, while internal parties such as employees. We can imagine if our relationship with them is not harmonious, can our business run smoothly which in the end involves our business, I don't think so.

5. The fifth strategy and way to develop a business is to try hard, be serious and want to learn. This is what we must do if we want the business we have worked so hard to pioneer to grow. 


\section{RESEARCH METHODS}

\section{Research Design}

This research is qualitative in nature by analyzing the impact of covid 19 in the development of business groups of students of the accounting study program at the PGRI Jember Accounting Academy. This type of research is descriptive research with a qualitative approach because the mindset is not easy to observe directly and not easy to measure quantitatively (Montessori 2006:5). According to Miles and Huberman (1992:1) the analysis occurs from three flow of activities that simultaneously occur data reduction, data presentation, conclusion drawing/verification. The data was obtained from students majoring in accounting at the Akademi Akuntansi PGRI Jember who are entrepreneurial as the object of research. The type of data used in this research is qualitative data. The data source used is primary data. While the data collection technique is using the interview method, literature study, documentation and sampling technique. The sampling technique used by the author is Non Probability Sampling. According to Sugiyono (2015:84) the notion of Non Probability Sampling is as follows: "Techniques that do not provide equal opportunities/opportunities for each element or member of the population to be selected as samples".

Considering the number of students whose business groups are not too many, of course this is quite easy to do. The following is a table of the student's efforts:

Table 1. Student Business

\begin{tabular}{|c|c|c|}
\hline No & Student Group & business name \\
\hline 1. & Business Group I & $\begin{array}{l}\text { Editing Video \& } \\
\text { Animasi }\end{array}$ \\
\hline 2. & Business Group II & $\begin{array}{l}\text { Beauty and } \\
\text { Massage }\end{array}$ \\
\hline 3. & Business Group III & Beauty Flower \\
\hline 4. & Business Group IV & HiDRum \\
\hline 5. & Business Group V & RnB Lights \\
\hline 6. & Business Group VI & Lotus Id. \\
\hline 7. & Business Group VII & Wall DECO \\
\hline 8. & Business Group & Titanik \\
\hline & VIII & Colection \\
\hline 9. & Business Group IX & Taoenng Shop \\
\hline
\end{tabular}

Source: Processed Data

\section{RESULTS OF ANALYSIS AND INTERPRETATION}

Based on the data from observations and interviews with the research sample, namely students majoring in accounting at the Akademi Akuntansi PGRI Jember, there are 5 instruments that are analyzed based on strategies and methods that we can do in an effort to develop a business. Researchers determine the research subjects, each student who is an entrepreneur. From the results of observations and interviews the authors can describe as follows:

\section{a. The first strategy and method is to process the products owned.}

The impact of covid 19 in the development of business groups for students of the accounting study program at the Akademi Akuntansi PGRI Jember, in terms of processing the products they own.

"During a pandemic like this, the production of photo editing and shooting services has decreased sharply, because our consumers 
such as weddings, birthdays and graduations, almost everything that has been ordered has been canceled due to social distancing reasons. So that production has stalled by almost $60 \%$, so our products due to services have decreased quite a bit."

\section{Source: Business Group I}

"Our business group that is engaged in wall deco for production in product manufacturing continues as usual, but for many materials that are empty in the store, because the store has a pandemic reason so that the delivery of the materials we need in production is a bit time consuming, here we also have to be smart- smart to give reasons to consumers who have ordered and ask for additional time in the completion of the product ".

\section{Source: Business Group VII}

"In terms of product processing, because here the ingredients that I use in this beauty and massage business we produce using natural ingredients and are easy to get in traditional markets, while they don't really affect the production. we buy the important thing is the stock of products for beauty and massage is safe"

\section{Source: Business Group II}

From the results of the analysis in terms of processing the products owned, it can be said that this student business group is experiencing problems with decreasing product processing, ranging from order cancellations, scarce raw materials, and raw material prices that tend to rise from the usual price.

\section{b. The second strategy and method is to develop by doing promotions, advertising consistently.}

The impact of covid 19 in business development for students of the accounting study program at the PGRI Jember Accounting Academy, in terms of doing promotions/advertising consistently.

"Promotion in this business is very important because the Beauty Flower business is different from other businesses because even though it is a replica, the raw materials are used goods. So that promotions must be really good at making sentences so that people are interested in our products. During the covid19 period, like today, there are no problems with promotions, the same as before there was covid, via WA, Facebook, Instagram and other social media, the only problem is that buyers are reduced because they prioritize basic ingredients, he explained.

\section{Source: Business Group III}

"All businesses need promotion, especially like the Titanic Collection, which sells miniature ships that not everyone likes. For promotions other than promos on social media, we usually take part in exhibitions or Expos held by campuses or local governments, but since the beginning of March there are no exhibitions so we rely on promos via cellphones. For clear sales, it's down".

\section{Source: Business Group VIII}

From the results of the analysis in terms of doing promotions/advertising consistently. Here it can be seen that almost the average use of social media, but there are also those who use events such as maeran but the results also experience a decrease in sales".

\section{c. The third strategy and way to develop a business is to provide affordable and competitive prices, and provide maximum service to consumers/customers.}

The impact of covid 19 on business development for students of the accounting study program at the Akademi Akuntansi PGRI Jember, in terms of pricing and service.

"Wow, if the problem with our service to customers is extraordinary, during the covid19 season like this, our customers' wishes are obeyed, starting from requests for 
discounts to adding tools, even though our profits can be depleted."

\section{Source: Business Group IV}

"The service we provide is more than usual in the RnB Lights business, installing installers, the point is that the customer accepts the life of the decorative lights and is satisfied. Even though before covid 19 it was usually installed by itself if someone asked for the installation to be installed there would be an additional fee, for now it is free because it includes services".

\section{Source: Business Group V}

"In pampering consumers of the Beauty and Massage business during a pandemic like this, we can improve it even more, such as free massage, cut stiff or eyebrow shape, the important thing is that customers are happy and want to use our services again"

\section{Source: Business Group II}

From the results of the analysis in terms of pricing and service, that the provision of prices and services has increased starting from giving discounts, providing additional services, the most important thing is that consumers are satisfied even though profits are thin.

\section{d. The fourth strategy and method is to try to establish a harmonious relationship with the internal and external parties of the company.}

The impact of covid 19 in business development for students of the accounting study program at the Akademi Akuntansi PGRI Jember, in terms of establishing harmonious relationships with internal and external parties of the company.

"Lotus Id is a therapeutic lamp business where in establishing relationships with fellow members (internal) in this business it is still maintained even though we have to keep a distance from covid19 conditions during production, as well as maintaining relationships with customers (externals) we must remain communicative so that we know about therapeutic lamp products. like what can make sleep comfortable ".

\section{Source: Business Group IV}

"If there is a business like ours, the Taoneng business, namely the picture and painting business, there is no significant change in maintaining relationships with business members and customers, because in this business, customers only need to send photos via e-mail or WA, so we can share the process with members. businesses and customers do not need to come to our place of business".

\section{Source: Business Group IX}

From the results of the analysis in terms of establishing harmonious relationships with internal and external parties of the company, the relationship between business members remains well established despite maintaining a distance in production, while the customers continue to maintain relationships as usual, only more communicative.

\section{e. The fifth strategy and way to develop a business is to try hard, be serious and want to learn.}

The impact of covid 19 on business development Students of the accounting study program at the Akademi Akuntansi PGRI Jember, in terms of trying hard, being serious and willing to learn.

"There is a lesson in this pandemic in the photography editing and shooting business, because when we have no work, we learn a lot more about photo editing and shooting, adding to the animation treasury, so we are serious and work hard to continue to develop ideas and continue to learn to use time. spare".

\section{Source: Business Group I}

"This beauty flower business with the existence of covid19 makes us fellow business members to strengthen each other if someone is down, and to continue to create 
creativity and innovation in terms of the models that we will sell".

\section{Source: Business Group III}

"Everything must have a lesson, yes, behind the Covid 19 disaster that has occurred in this world, and we did not expect that the effect would be so great in this $\mathrm{RnB}$ light effort, we are more enthusiastic about how this business does not die, with hard work, continue to study seriously, thank God can still survive even though it's hard"

\section{Source: Business Group V}

From the results of the analysis in terms of trying hard, being serious and willing to learn. That determination in business is to try hard, be sincere and willing to learn by continuously creating creativity and innovation, developing ideas and increasing enthusiasm.

\section{CONCLUSION}

Based on the results of research and discussion of the impact of covid 19 in Business Group Development, students of the accounting study program at the Akademi Akuntansi PGRI Jember can be taken with 5 business development strategy instruments as follows:

1. From the results of the analysis in terms of processing the products owned. that this student business group can be said to be experiencing problems with product processing, ranging from order cancellations, scarce raw materials, and raw material prices which tend to rise from the usual price.

2. From the results of the analysis in terms of doing promotions/advertising consistently. Here it can be seen that almost the average use of social media, but there are also those who use events such as maeran but the results also experience a decrease in sales.

3. From the results of the analysis in terms of pricing and service, that the provision of prices and services has increased starting from giving discounts, providing additional services, the most important thing is that consumers are satisfied even though profits are running low.

4. From the results of the analysis in terms of establishing harmonious relationships with internal and external parties of the company, the relationship between business members is still well established despite maintaining a distance in production, while customers continue to maintain relationships as usual, only more communicative.

5. From the results of the analysis in terms of trying hard, being serious and willing to learn. That determination in business is to try hard, be sincere and willing to learn by continuously creating creativity and innovation, developing ideas and increasing enthusiasm.

\section{REFERENCES}

French, Wendell L, Cecil H. Bell, Jr, Robert A. Zawacki (ed.) (2000);Organization Development andTransformation; Irwin McGrall-Hill Singapore.

Hendro,Ir.M.M.(2011). Dasar-dasar kewirausahaan. Jakarta: Erlangga.

https://nasional.kontan.co.id/news/inidelapan-dampak-negatif-bagiperekonomian -indonesia-akibatwabah-virus-corona/ (19 April 2020).

https://kbbi.web.id/dampak/ (19 April 2020)

https://www.who.int/indonesia/news/novelcoronavirus/qa-for-public (19 April 202)

http://ilmuuntukibadah.blogspot.com/2016/0 5/bab-7-strategi-pengembanganusaha.html ( 30 April 2020 )

Kasali, Rhenald . dkk. 2010 . Modul Kewirausahaan. Jakarta Selatan. Hikmah ( PT. Mian Publika).

Madya, Buang Noer A dan Isteti, Prinsipprinsip Kewirausahaan, 2006; Fakulti 
Pendidikan Universiti Kebangsaan Malaysia

Miles dan Huberman .1992 . Analisis Data Kualitatif. Jakarta. Univesitas Indonesia Press

Montessori, Maria . 2006. "Pola Pikir Guru SMA Tentang Perannya dalam
Mengajarkan

Kewarganegaraan. "Forum Pendidikan (31) $1: 1-12$

Sugiyono .2015. Metode Penelitian Kombinasi (Mix Methods). Bandung: Alfabeta. 